\title{
Power in context: the Lismore landscape project
}

\author{
D.I. Redhouse, M. ANDERSon, T. Cockerell, S. Gilmour, R. HOUSLEy, C. MAlone \\ \& S. STODDART*
}

Modern studies of Iron Age landscapes in Scotland have concentrated on the outer islands (e.g. Parker Pearson \& Sharples 1999; Harding 2000), and most recently on areas such as Caithness (Heald \& Jackson 2001). Argyll (FIGURE 1) has been recently designated a 'black hole' in terms of current knowledge (Haselgrove et al. 2001: 25). Although this description underestimates the work of the Royal Commission survey of Argyll (RCAHMS 1975), further work is needed to allow comparative models of settlement organization. The Royal Commission recovered evidence for 14 sites - brochs, duns and forts - broadly defined as Iron Age. The current project will build on these foundations by analysis of aerial photographs and systematic survey, followed by detailed topographical and geophysical survey of earthworks and selective excavation. The aim is to understand the changing landscape of the period $1000 \mathrm{BC}-\mathrm{AD} 1000$, through a reconstruction of the precise dated development of settlement against the pattern of land-use, leading to new models of economic and political organization.

Work by one of us (TC) provided systematic aerial photographic cover of the island at 1:6000 on 3 May 2000 (e.g. FIGURE 2), which will be employed to identify sites and, after ground truthing by GPS, will provide an enhanced Digital Elevation Model. A desktop study (2001-2) (by DIR) drew on the Ordnance survey (OS) digital mapping data provided through the JISC/ EDINA Digimap scheme and the site database of the National Monuments Record of Scotland (RCAHMS). These data were analysed in ESRI ArcInfo 8.0.1 on Solaris 7 to ask some basic spatial questions of the known archaeological sites on the island: notably most Iron Age sites were placed so as to have maximum visual control of the maritime approaches from the nearest mainland to the southeast (e.g. FTGURE 3).

The first fieldwork (August 2002) concentrated on the systematic recording of the monument of Tirefour, the best-known Iron Age site on the island. A detailed topographic survey was implemented to investigate this site's geographical context and to detect outworks to the main defended area. The topographic survey
(FIGURE 4) confirms details of the defensive outworks on the Tirefour ridge, highlights associated sub-rectangular buildings which do not appear on 1875-1900 OS sheets, and outlines a platform below the broch to the north, and records the process of decay of the monument since the RCAHMS survey of May 1968. During the 2002 season, all known prehistoric sites on the island were visited and their condition compared with the record made in the RCAHMS survey. In particular, a comparative viewshed using digital photography was constructed (by MA) of a sample of sites (e.g. FIGURE 5) which will be compared with computer-generated viewsheds and displayed on the project website <http://www.arch.cam.ac.uk/lismore/>.

A pilot study of the potential for environmental reconstruction in the nearest loch to Tirefour (by $\mathrm{RH}$ ) comprised augering at the northeast end of Balnagowan (Baile a'Ghobhainn) loch which recorded a peat and marl sequence in excess of $6 \mathrm{~m}$. Towards the northeast margin of the deposit, a full 4-m sequence was recovered with alternating layers of fen carr peat and marl over a silt of probable late glacial age. This sequence, in conjunction with the potentially high preservation of calcareous soils for excavated ecofacts, gives great hope for detailed environmental and economic reconstruction.

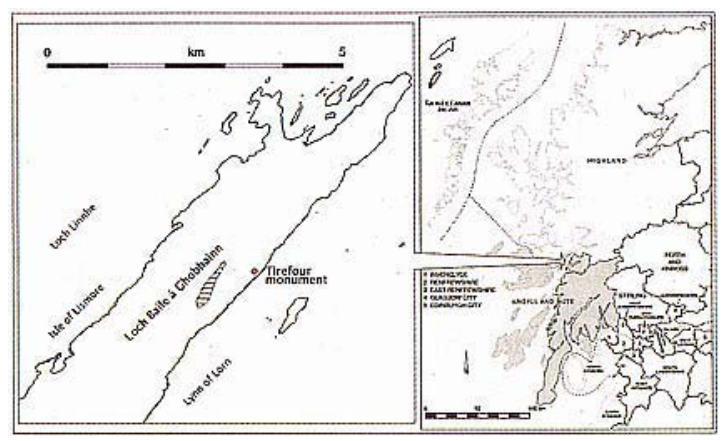

FIGURE 1. Map showing location of Tirefour in relationship to Balnagowan loch.

* Redhouse, Department of Archaeology, University of Cambridge, Downing Street, Cambridge CB2 3DZ, England.

d.i.redhouse@arch.cam.ac.uk Anderson, Corpus Christi College, Cambridge CB2 1RH, England. maa35@hermes.cam.ac.uk Cockerell, Committee for Aerial Photography, Free School Lane, Cambridge CB2 3RF, England. tfc1000@cam.ac.uk Gilmour, Royal Commission on the Ancient \& Historical Monuments of Scotland, 16 Bernard Terrace, Edinburgh EH8 9NX, Scotland. Simongi@rcahms.gov.uk Housley, Department of Archaeology, University of Glasgow, Glasgow G12 8QQ, Scotland. R.Housley@archaeology.arts.gla.ac.uk Malone, Department of Prehistory \& Early Europe, British Museum, London WC1B 3DG, England. cmalone@british-museum.ac.uk Stoddart, Magdalene College, Cambridge CB3 0AG, England. ss16@cam.ac.uk 
Figure 2. Aerial photo of Tirefour. (By kind permission of CUCAP.)

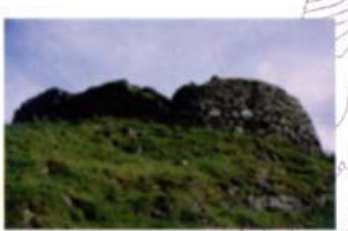

FIGURE. 6. View of Tirefour from the northwest.
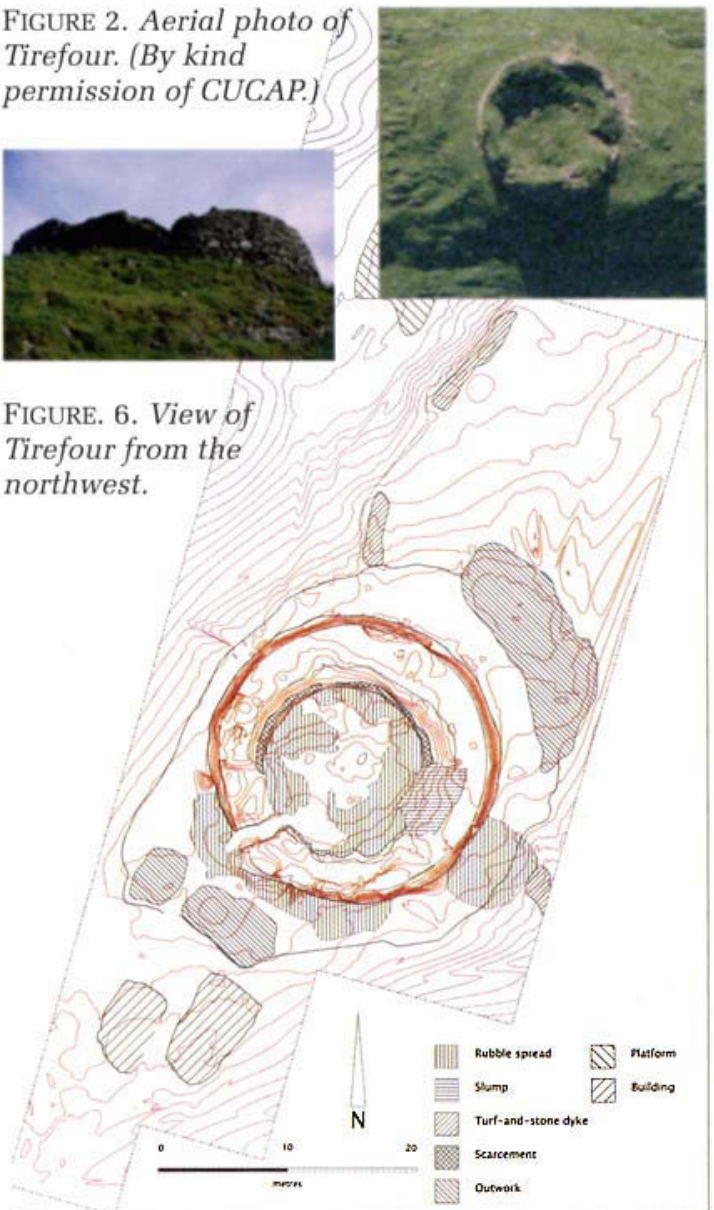

FIGURE 4. Detailed topographic plan of Tirefour.

Initial work on the island of Lismore ( 2229 ha ( $c$. $15.4 \times 2.3 \mathrm{~km})$ ) shows the great potential for a detailed picture of an Iron Age landscape. Tirefour (FIGURE 6) was located within a fertile area of the island, and it is the understanding and development of this relationship which will be investigated by a battery of interdisciplinary techniques over the next two years, against a broader pattern of Iron Age sites throughout the whole island.

Acknowledgements. For fiaance: Historic Scotland, the Cook Trust, the University of Cambridge and Magdalene College, Cambridge.

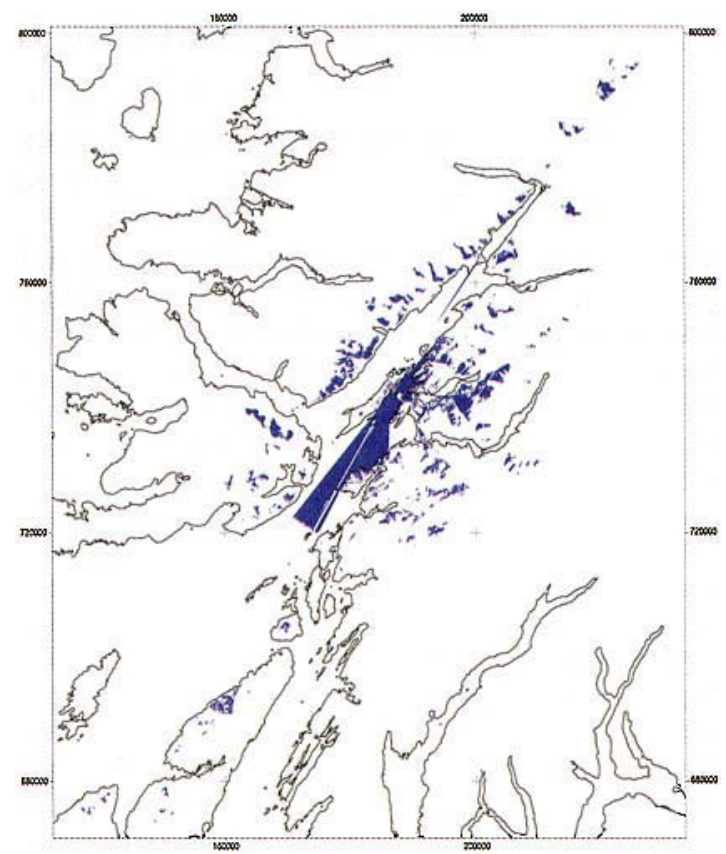

FIGURE 3. Viewshed from Tirefour generated in ESRI ArcInfo 8.0.1 on Solaris 7. DEM taken from OS PANORAMA data set. Observer height $5 \mathrm{~m}$. (Crown copyright Ordnance Survey.)

For other support: The Cambridge Conmittee for Aerial Photography (CUCAP), the ISC/EUINA Digimap scheme, the National Monuments Record of Scotland in the Royal Commission on the Ancient and Historical Monuments of Scotland, The Historical Society of Lismore, the White and Kayll families and many individuals from Lismore.

\section{References}

HARDING, D.W. 2000. The Hebridean Iron Age: twenty years' research. Edimburgh: Department of Archaeology. Occasional Paper 20.

Haselgrove, C. I. ARMit, T. Champion, J. Creighton, A. GWLt, J.D. HII., F. HUNTER \& A. WOODWARD. 2001. Understanding the British Iron Age: An Agenda for Action: A report for the Iron Age Research Seminar and the Council of the Prehistoric Society. Salisbury: Trust for Wessex Archaeology.

HEALD, A. \& A. JACKSON, 2001. Towards a new understanding of Iron Age Caithness, Proceedings of the Society of Antiquaries of Scotland 131: 129-47.

PARKER PEARSON, M. \& N. SHARPLES. 1999. Between land and sea. Excavations at Dun Vulan, South Uist. Sheffield: Sheffield Academic Press.

RCAHMS 1975 Argyll. An Inventory of Ancient Monuments 2: Lorn. Edinburgh: RCAHMS.

FIGURE 5. Photographic viewshed from Tirefour.

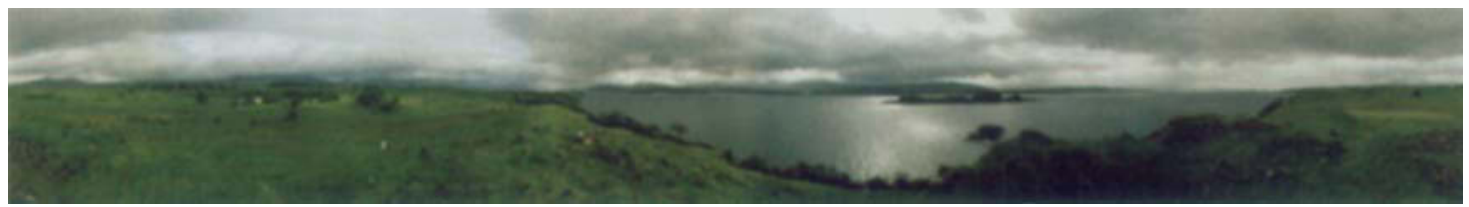

